\title{
GEOGRAPHICAL VARIATIONS IN THE EPIDEMIC OF ASTHMA DEATHS
}

\author{
PATRICIA FRASER AND RICHARD DOLL \\ Medical Research Council's Clinical Research Centre, Harrow, and Department of Regius Professor of Medicine, \\ University of Oxford
}

The mortality rate from asthma increased sharply between the years 1959 and 1966 in England and Wales, and to a lesser extent in some other countries (Speizer, Doll, and Heaf, 1968). After March 1967 there was a profound fall in the number of deaths from asthma in all age groups in England and Wales (Inman and Adelstein, 1969). We have therefore re-examined the trends in other countries, and report here the geographical variations in asthma mortality that have been observed during the 10-year period from 1959 to 1968 . The study is confined to mortality at ages 5 to 34 years, partly because the changes were most pronounced in this age group in England and Wales, and partly because death due to bronchitis at these ages is uncommon, and confusion over the cause of death is unlikely.

\section{ENGLAND AND WALES}

The rise and fall of asthma mortality in Englan\$ and Wales between the years 1959 and 1968 has beeñ described in detail by Inman and Adelstein (1969). Between 1961 and 1966 the mortality increased cons siderably. By 1966 the rate had risen to $2 \cdot 18$ pets 100,000 persons aged 5 to 34 years, $230 \%$ higher than the 1959 level of 0.66 per 100,000 (Table I) Even more seriously affected was the age group 18 to 19 years in which the number of deaths rose to 171 in 1966 compared with 39 in 1959, the respective rates being 2.46 and 0.49 per 100,000 (Table II).

In England and Wales the mortality from asthmon

TABLE I

MORTALITY FROM ASTHMA AT AGES 5 TO 34 YEARS IN DIFFERENT COUNTRIES, 1959-68

\begin{tabular}{|c|c|c|c|c|c|c|c|c|c|c|}
\hline \multirow{2}{*}{ Country } & \multicolumn{10}{|c|}{ Death Rate per 100,000 Persons in } \\
\hline & 1959 & 1960 & 1961 & 1962 & 1963 & 1964 & 1965 & 1966 & 1967 & 1968 \\
\hline $\begin{array}{l}\text { England and Wales } \\
\text { Scotland } \\
\text { Republic of Ireland } \\
\text { Australia } \\
\text { New Zealand } \\
\text { Sweden } \\
\text { Denmark } \\
\text { Federal Republic of Germany } \\
\text { Netherlands } \\
\text { Belgium } \\
\text { U.S.A. } \\
\text { Japan }\end{array}$ & $\begin{array}{l}0.66 \\
0.82 \\
0.90 \\
1.06 \\
0.81 \\
0.15 \\
0.39 \\
0.42 \\
0.24 \\
0.37 \\
0.71\end{array}$ & $\begin{array}{l}0.68 \\
1.08 \\
0.45 \\
0.89 \\
0.88 \\
0 . \overline{15} \\
0.41 \\
0.68 \\
0.42 \\
0.41 \\
0.86\end{array}$ & $\begin{array}{l}0.89 \\
0.79 \\
0.71 \\
1.23 \\
0.78 \\
0.64 \\
0.24 \\
0.53 \\
0.35 \\
0.24 \\
0.40 \\
0.84\end{array}$ & $\begin{array}{l}1.00 \\
0.70 \\
0.55 \\
1.15 \\
0.92 \\
0.48 \\
0.19 \\
0.42 \\
0.42 \\
0.36 \\
0.43 \\
0.89\end{array}$ & $\begin{array}{l}1.40 \\
1.23 \\
0.47 \\
1.03 \\
0.82 \\
0.51 \\
0.34 \\
0.45 \\
0.52 \\
0.46 \\
0.41 \\
0.99\end{array}$ & $\begin{array}{l}1.76 \\
1.63 \\
1.18 \\
1.70 \\
1.03 \\
0.76 \\
0.24 \\
0.59 \\
0.42 \\
0.38 \\
0.36 \\
1.03\end{array}$ & $\begin{array}{l}2.05 \\
1.32 \\
1.42 \\
1.60 \\
1.24 \\
0.31 \\
0.28 \\
0.54 \\
0.55 \\
0.65 \\
0.42 \\
1.00\end{array}$ & $\begin{array}{l}2.18 \\
2.59 \\
1.06 \\
1.88 \\
2.87 \\
0.62 \\
0.66 \\
0.63 \\
0.51 \\
0.37 \\
0.41 \\
1.01\end{array}$ & $\begin{array}{l}1.76 \\
1.77 \\
1.36 \\
1.44 \\
1.99 \\
0.55 \\
0.42 \\
0.56 \\
0.59 \\
0.58 \\
1.01\end{array}$ & 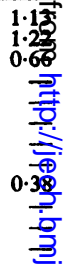 \\
\hline
\end{tabular}

TABLE II

MORTALITY FROM ASTHMA AT AGES 10 TO 19 YBARS IN DIFFERENT COUNTRIES, 1959-68

\begin{tabular}{|c|c|c|c|c|c|c|c|c|c|c|}
\hline \multirow{2}{*}{ Country } & \multicolumn{10}{|c|}{ Death Rate per 100,000 Persons in } \\
\hline & 1959 & 1960 & 1961 & 1962 & 1963 & 1964 & 1965 & 1966 & 1967 & \\
\hline $\begin{array}{l}\text { England and Wales } \\
\text { Scotland } \\
\text { Republic of Ireland } \\
\text { Australia } \\
\text { New Zealand } \\
\text { Sweden } \\
\text { Denmark } \\
\text { Federal Republic of Germany } \\
\text { Netherlands } \\
\text { Belgium } \\
\text { U.S.A. } \\
\text { Japan }\end{array}$ & $\begin{array}{l}0.49 \\
0.49 \\
0.39 \\
0.60 \\
0.25 \\
0.13 \\
0.17 \\
0.10 \\
0.08 \\
0.21 \\
0.25\end{array}$ & $\begin{array}{l}0.45 \\
1 \cdot 33 \\
0.00 \\
0.97 \\
0 \cdot 71 \\
0.00 \\
0.14 \\
0.24 \\
0.24 \\
0.25 \\
0.36\end{array}$ & $\begin{array}{l}0.71 \\
0.61 \\
0.38 \\
1.04 \\
0.23 \\
0.25 \\
0.37 \\
0.12 \\
0.09 \\
0.08 \\
0.28 \\
0.34\end{array}$ & $\begin{array}{l}0.98 \\
0.48 \\
0.00 \\
1.00 \\
0.67 \\
0.41 \\
0.12 \\
0.09 \\
0.14 \\
0.00 \\
0.27 \\
0.39\end{array}$ & $\begin{array}{l}1 \cdot 10 \\
0.60 \\
0.19 \\
1.07 \\
0.85 \\
0.58 \\
0.37 \\
0.27 \\
0.22 \\
0.22 \\
0.29 \\
0.56\end{array}$ & $\begin{array}{l}1.64 \\
2.04 \\
0.57 \\
1.58 \\
1.03 \\
0.67 \\
0.00 \\
0.34 \\
0.22 \\
0.36 \\
0.32 \\
0.63\end{array}$ & $\begin{array}{l}1.99 \\
1.44 \\
1.15 \\
1.64 \\
0.99 \\
0.52 \\
0.13 \\
0.22 \\
0.39 \\
0.56 \\
0.35 \\
0.64\end{array}$ & $\begin{array}{l}2.46 \\
2.74 \\
0.55 \\
1.83 \\
2.73 \\
0.44 \\
0.91 \\
0.33 \\
0.35 \\
0.48 \\
0.33 \\
0.68\end{array}$ & $\begin{array}{l}1.83 \\
1.84 \\
1.28 \\
1.34 \\
2.10 \\
0.53 \\
0.92 \\
0.43 \\
0.26 \\
0.31 \\
0.66\end{array}$ & 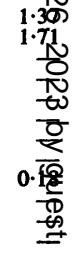 \\
\hline
\end{tabular}


began to decline in the second quarter of 1967 and continued to fall throughout 1968 . Provisional data for 1969 show that the mortality rates were at all ages lower than those in 1968 and equal to, or slightly above, those in 1959-60.

Inman and Adelstein examined these trends in mortality attributed to asthma in relation to the trends in the use of pressurized aerosols containing sympathomimetic bronchodilators. They considered the various factors that might have influenced the observed trends and concluded that 'the increase in mortality from asthma that was observed during the years 1961 to 1966 , was likely to have been due to the excessive use of pressurized aerosol bronchodilators and that the subsequent reduction in mortality resulted from a greater awareness among the medical profession and the patients themselves of the hazards of these devices if improperly used'. Further evidence to suggest that excessive use of inhaled bronchodilators may have contributed to death is provided by a study of the circumstances preceding death in young asthmatics (Fraser, Speizer, Doll, Waters and Mann, 1971).

\section{SCOTLAND}

In Scotland the death rate from asthma at ages 5 to 34 years increased rapidly after 1962 and reached a peak in 1966 when the rate was 2.59 per 100,000 persons. This was even higher than the mortality in England and Wales in the same year and represented an increase of $173 \%$ above the $1959-60$ level. At ages 10 to 19 years the death rate rose to 2.74 per 100,000 persons in 1966 . Deaths from asthma decreased in 1967 and there was a further fall in 1968.

\section{REPUBLIC OF IRELAND}

In the Irish Republic the increase in mortality at ages 5 to 34 years was not apparent until 1964 and was then less marked than in England and Wales. In 1965-7 the average annual death rate was $1 \cdot 28$ per 100,000 persons, $90 \%$ above the figure for 1959-60. In 1968 the mortality rate returned to its previous level.

\section{Australia}

Until 1964 Australian death rates from asthma at ages 5 to 34 years were relatively stable with an average yearly rate of about 1 per 100,000 persons. The mortality began to rise in 1964 , reached a peak in 1966 (by which time the death rate had increased by $93 \%$ above the $1959-60$ level), and decreased in 1967. A similar trend in mortality was observed at ages 10 to 19 years.

\section{New Zealand}

In 1959 the death rate from asthma in New Zealand at ages 5 to 34 years was 0.81 per 100,000 persons and this level was maintained approximately for the following four years. From 1964 to 1966 there was a sudden rise in mortality and the peak death rate in 1966 was 2.87 per 100,000 persons, an increase of $240 \%$ over the level for 1959-60. Although the numbers of deaths each year were small, the age group 10 to 19 years showed a similar peak in 1966, when 14 deaths occurred compared with five or less in all previous years.

The increase in the death rate from asthma in New Zealand between 1959 and 1966 at ages 5 to 34 years exceeded even the substantial increases seen in England and Wales, and Scotland, during this period. As in Britain, the epidemic in New Zealand started to decline in 1967.

\section{WESTERN EUROPE}

Among the countries of Western Europe for which five-year age-specific rates were available for most of the period, Denmark, Belgium, and the German Federal Republic showed small increases in mortality in both the age groups 5 to 34 years and 10 to 19 years, reaching a maximum between 1965 and 1967. No appreciable increases were recorded in Sweden or the Netherlands. The random fluctuation in mortality rates which may occur in countries with few asthma deaths and small populations is noticeable in the figures for Denmark, Sweden, and Belgium, with total populations of less than 10 million.

\section{United States of America}

In the United States of America there was no appreciable increase in mortality from asthma at ages 5 to 34 between 1959 and 1967. The death rate varied from 0.37 per 100,000 persons in 1959 to a maximum of 0.43 in 1962 . At ages 10 to 19 years there was a small increase in mortality from 0.21 in 1959 to 0.35 per 100,000 in 1965 , and a fall in the following two years. The increase in 1966 that was reported by Speizer et al. (1968) was based on provisional figures and was not confirmed when the definitive rates were published.

\section{JAPAN}

In Japan there was a slow increase in mortality at ages 5 to 34 years from 1959 to 1964, by which time the death rate had increased by $45 \%$. A much greater increase of $152 \%$ was seen at ages 10 to 19 years when the number of deaths rose from 51 in 1959 to 126 in 1964 . Since 1964 the mortality rates 
have remained constant with an average yearly rate of 1.01 and 0.65 per 100,000 persons at ages 5 to 34 and 10 to 19 years respectively.

\section{Aerosol Sales}

It has not been possible to obtain comparable figures for the consumption of pressurized aerosols containing sympathomimetic bronchodilators in these countries. Gandevia (1968), however, has reported an approximately contemporaneous increase in the sale of these preparations in Australia, and Lineham (1970) has reported a similar increase in the Republic of Ireland. Lineham's observations are of particular interest as the sale of the drugs in Ireland increased more slowly and reached a lower total than in England and the increase in mortality was later and less marked.

\section{SUMmaRY}

The trends in mortality from asthma at ages 5 to 34 years observed in 12 countries between 1959 and 1968 fall into three fairly distinct groups. England and Wales, Scotland, and New Zealand all showed a marked increase in mortality which reached a peak in 1966 and subsequently declined. The Republic of Ireland and Australia showed a similar trend, but the increases in mortality were less marked. This trend contrasts with that seen in Denmark, Belgium, the German Federal Republic, and Japan where the increases in mortality were small, and where there was a tendency for the maximum value reached to be maintained. There was no appreciable change in asthma mortality in the U.S.A. or the Netherlands.

Within the age group 5 to 34 years the increase. in mortality was most marked at ages 10 to 19 years and at these ages the subsequent decrease was lesह marked or failed to occur. At these ages there was also some slight increase in mortality in the U.S.A and the Netherlands.

We are grateful to the Registrar General for providing information about the provisional age-specific mortality rates for 1969.

\section{REFERENCES}

Fraser, P. M., Speizer, F. E., Doll, R., Watersథ S. D. M., and MANN, N. M. (1971). The circumstances preceding death from asthma in young people inj 1968-69. Brit. J. Dis. Chest, in press.

GaNDEVIA, B. (1968). The changing pattern of mortality from asthma in Australia: 2. Mortality and modern therapy. Med. J. Aust., 1, 884.

INMAN, W. H. W., and Adelstein, A. M. (1969). Rise and fall of asthma mortality in England and Wales in re lation to use of pressurised aerosols. Lancet, 2, 279.

LiNeHAM, W. D. (1970). Paper presented at the annuaf meeting of the Irish Medical Association, 1970. (See Doll, R., and Fraser, P., 'An Epidemic of Asthma Deaths and its Relation to Drug Therapy'. Reporfore the Twelfth Meeting of the European Society for the Study of Drug Toxicity, in press.)

SPeizer, F. E., Doll, R., and HeAF, P. (1968). Observa乏 tions on recent increase in mortality from asthma Brit. med. J., 1, 335. 